\title{
Effects of Imidacloprid on Spider Mite (Acari: Tetranychidae) Abundance and Associated Injury to Boxwood (Buxus spp.)
}

\author{
Adrianna Szczepaniec and Michael J. Raupp
}

\begin{abstract}
Boxwoods are one of the most widely used woody shrubs in managed landscapes, but they suffer frequent attack by the boxwood leafminer (Monarthropalpus flavus). The neonicotinoid insecticide imidacloprid is highly efficacious in reducing the abundance of $M$. flavus when applied as a foliar spray or a soil drench. Recent reports of elevated populations of spider mites following applications of imidacloprid to other species of woody plants prompted an investigation to determine the effects of imidacloprid on abundance of a specialist spider mite, Eurytetranychus buxi, and the resultant damage it causes. Boxwoods treated with imidacloprid housed significantly more E. buxi and sustained more discoloration than untreated boxwoods. Moreover, there was a direct relationship between the abundance of $E$. buxi and the amount of associated injury. Arborists and landscape managers should be aware of the potential for elevated abundance of spider mites on boxwoods and greater levels of discoloration following applications of imidacloprid. Key Words. Buxus spp.; Eurytetranychus buxi; Imidacloprid; Injury; Monarthropalpus flavus; Secondary Pest Outbreak.
\end{abstract}

The boxwood leafminer (Monarthropalpus flavus) is one of the most important insect pests of boxwoods in nurseries and landscapes owing to the widespread use of Buxus spp. in planting designs and the propensity of boxwoods to incur infestations of this pest (Holmes and Davidson 1984; Gagne 1989; Batdorf 1994; d'Eustachio and Raupp 2001). In the early 2000s, applications of conventional insecticides, such as carbamates and organophosphates to control boxwood leafminer (Schread 1970) gave way to a new class of insecticides, neonicotinoids. Imidacloprid in particular proved to be highly efficacious in controlling boxwood leafminer when applied as a foliar spray (d'Eustachio and Raupp 2001) or as a soil injection (Gill et al. 2002). Soon after the appearance of imidacloprid in the horticultural arena, reports surfaced regarding the outbreak of secondary pests, particularly spider mites, on plants treated with imidacloprid. Elevated populations of spider mites following the use of imidacloprid occurred on honeylocust (Gleditsia triacanthos) (Sclar et al. 1998), eastern hemlock (Tsuga canadensis) (Raupp et al. 2004), American elms, (Ulmus americana) (Raupp et al 2008; Szczepaniec et al. 2011), and rose (Rosa sp.) (Gupta and Krischik 2007). Hypothetical mechanisms underlying elevated populations of spider mites include disruption of the abundance and activities of natural enemies, enhanced quality of plant foliage, and elevated fecundity of mites (Sclar et al. 1998; Gupta and Krischik 2007; Raupp et al. 2010; Szczepaniec et al. 2011).

Although several previous accounts documented elevated populations of mites following imidacloprid use, none sought to examine its effect on abundance of spider mites on boxwoods or the relationship between spider mite populations and associated injury to plant foliage. The objectives of this study were threefold. First, the researchers determined if a standard application of imidacloprid as a soil drench increased abundance of spider mites associated with boxwoods. Next, the researchers determined if plants treated with imidacloprid sustained more injury in the form of mite-induced discoloration compared to untreated plants. Finally, using regression analysis, the study authors sought evidence of a relationship between spider mite abundance and injury expressed as foliar discoloration.

\section{MATERIALS AND METHODS}

Boxwoods (B. sempervirens) used in this study were an element of a managed landscape on the campus of the University of Maryland (College Park, Maryland, U.S.). Boxwoods were components of trimmed hedges in mulched beds that received no supplemental water other than rain. In a completely randomized design, the study authors selected 20 boxwoods that were approximately $0.6 \mathrm{~m}$ tall and grew in rows separated by approximately $0.3 \mathrm{~m}$ between individual plants. At least two boxwoods in the hedge, separated treated plants from untreated ones, serve as buffers between treatments. Ten plants received imidacloprid applications and 10 other designated as untreated controls did not. On July 3, 2003, imidacloprid was applied as a soil drench formulation $\left(\right.$ Merit $^{\circledR}$ water soluble powder, $75 \%$ imidacloprid, Bayer, Research Triangle Park, North Carolina, U.S.) at the labeled rate of $2 \mathrm{~g} / 0.3 \mathrm{~m}$ of height dissolved in $200 \mathrm{ml}$ of water. Abundance of spider mites was evaluated at intervals of approximately one month from July through September by removing one shoot from each shrub, examining the terminal microscopically, and counting all eggs, nymphs, and adult mites on each of the five most distal leaves. Abundance of mites was expressed as the number per terminal. Each of the monthly estimates of mite abundance for each plant was summed over the three month interval of the study to calculate a cumulative estimate of mite abundance 
that was the response variable used for statistical analyses. As spider mites feed, they remove contents of cells. The resultant injury is characterized as a form of discoloration called stippling (Sadof and Alexander 1993; Lehman 1998; Shrewsbury and Hardin 2004). Because boxwoods did not shed new terminal leaves between July and September and because discoloration associated with mite feeding was cumulative during the interval of the study (Lehman 1998; Shrewsbury and Hardin 2004), injury was estimated on the date of the last sample, September 15, 2003. Injury related to the feeding of spider mites was quantified by visually examining the same five leaves from which mite abundance was determined and estimating by consensus to the nearest $5 \%$ the amount of leaf area discolored by spider mites (see Shrewsbury and Hardin 2004). The authors averaged injury estimates from the five leaves and used this average to compare the amount of mite-associated injury on treated and untreated plants.

Estimates of mite abundance and plant injury were heteroskedastic and homogeneity of variances was not accomplished through transformation. Therefore, comparisons of mite abundance and levels of injury between treated and untreated plants were conducted with a two-tailed Wilcoxon Rank Sum Test (Zar 1999; Statistix Analytical Software 2003). Also of interest was the relationship between abundance of spider mites on boxwoods and the amount of plant injury that they caused. To investigate this relationship, injury (percent discoloration) was regressed on mite abundance using linear regression analysis (Zar 1999; Statistix Analytical Software 2003).

\section{RESULTS AND DISCUSSION}

Application of imidacloprid increased the abundance of spider mites on boxwoods by roughly fourfold (Wilcoxon rank sum test, $\mathrm{P}=0.018$ ), and the amount of injury to boxwood leaves by nearly threefold (Wilcoxon rank sum test, $\mathrm{P}=0.024$ ) (Figure 1 ). A highly significant relationship was found between the average cumulative number of mites observed in a three-month period and the resulting amount of injury measured as percent of leaf discoloration $\left(\mathrm{F}=189.72 ; \mathrm{df}=1,18 ; \mathrm{P}=0.001 ; \mathrm{r}^{2}=0.91\right)$ (Figure 2$)$.

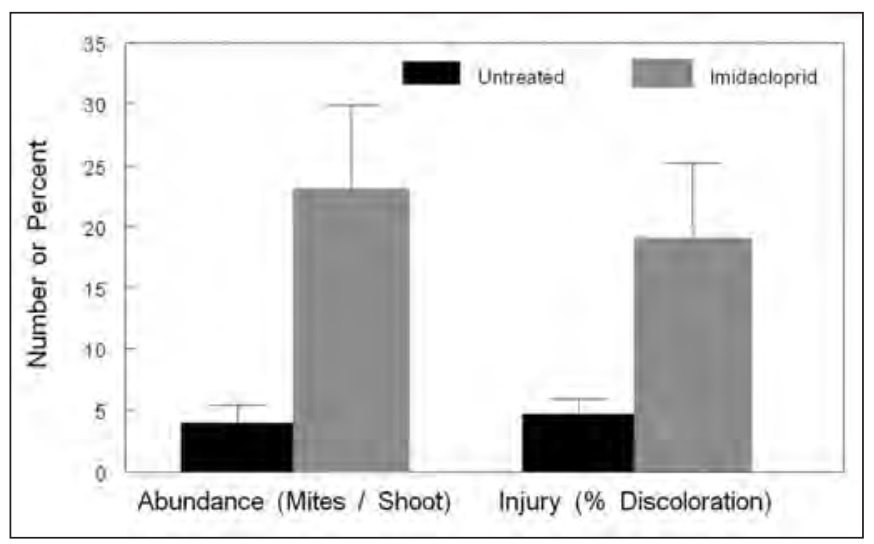

Figure 1. Effect of imidacloprid on the abundance (average number per shoot) of Eurytetranychus buxi and their injury (average percent of leaf area discolored) on Buxus sempervirens in a landscape bed. Abundance of spider mites and the resulting injury to boxwood leaves were significantly greater on shrubs that were treated with imidacloprid. Bars represent means and vertical lines represent standard errors.

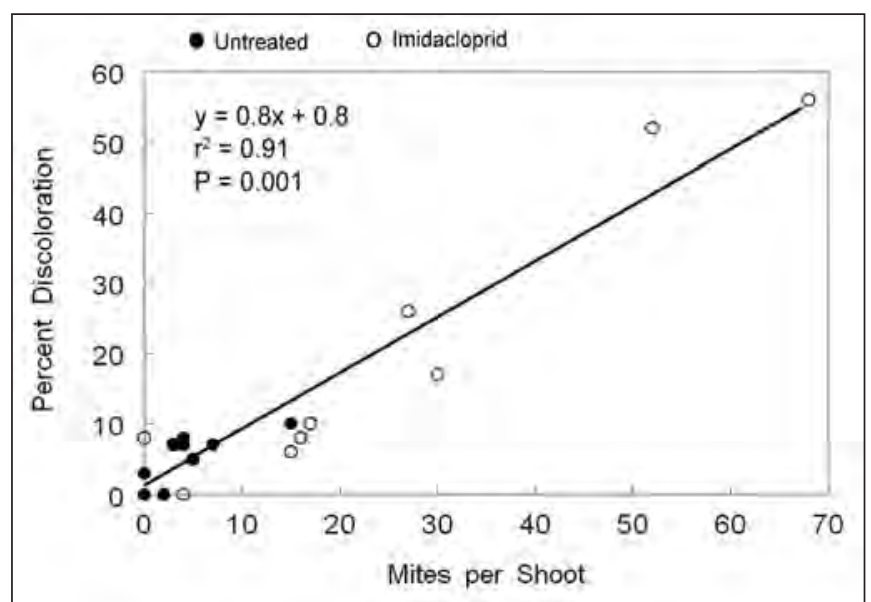

Relationship between abundance of Eurytetranychus buxi (average number of mites per shoot) and their injury (average percent of leaf area discolored) to Buxus sempervirens in a landscape bed. The solid line is the fitted least squares linear regression. Percent discoloration of boxwood leaves increased with spider mite abundance and reached over $50 \%$ at the greatest densities of spider mites.

The finding that an application of imidacloprid elevates populations of spider mites is consistent with results of studies of honeylocust spider mite (Platytetranychus multidigituli) on honeylocust, spruce spider mite (Oligonychus ununguis) on hemlock, Schoene spider mite (Tetranychus schoenei) on elm, southern red mite (Oligonychus ilicis) on cotoneaster (Cotoneaster salicifolius), and twospotted spider mite (Tetranychus urticae) on rose and euonymus (Sclar et al. 1998; Gupta and Krischik 2007; Chiriboga 2009; Szczepaniec 2009; Raupp et al. 2010; Szczepaniec et al. 2011). Elevated populations of spider mites following the use of imidacloprid are thought to result from disruption of the activity of predators of spider mites or through enhanced reproduction of spider mites as a result of improved plant quality or direct physiological stimulation (Sclar et al. 1998; Gupta and Krischik 2007; Chiriboga 2009; Raupp et al. 2010; Szczepaniec et al. 2011). It is noteworthy that $E$. buxi lay more eggs when feeding on plants exposed to imidacloprid, and the enhanced fecundity appears to be mediated by changes in plant quality following imidacloprid applications rather than direct stimulation of spider mite fecundity by the insecticide (Szczepaniec 2009).

Imidacloprid can significantly increase injury associated with feeding of spider mites. Raupp et al. (2004) reported severe discoloration associated with the feeding of spruce spider mite to be more frequent on hemlocks treated with imidacloprid. In addition, a greater proportion of hemlock branches sustained injury on treated hemlocks compared to untreated trees (Raupp et al. 2004). The fact that leaf injury was strongly linked to the abundance of spider mites on boxwoods is consistent with other known associations of spider mites and their woody hosts such as euonymus (Sadof and Alexander 1993) and spruce (Shrewsbury and Hardin 2004). Sadof and Raupp (1996) suggested that the general public has a low tolerance for disfigurement of valuable ornamental plants. They found that discoloration of $10 \%$ or more might trigger a management action such as a pesticide application. Because boxwoods treated with imidacloprid exhibited foliar discoloration well in excess of $10 \%$, while injury to untreated plants hovered around 5\%, arborists and landscape 
managers should be vigilant when treating boxwoods with imidacloprid. Plant health care technicians should prepare to intervene in the likely event that the abundance of spider mites on boxwoods and its associated injury will increase following an application of imidacloprid. Imidacloprid is one of the most frequently used insecticides in urban landscapes and with its long-lasting control of many pests of urban landscapes (Frank et al. 2007; Szczepaniec and Raupp 2007) it is likely to remain one of the leading insecticides. Additional research should focus on the relationship between the dose of insecticide that does not compromise its efficacy against the insect pests while alleviating the non-target effects on populations of spider mites.

Acknowledgments. The authors are grateful to the Department of Landscape Services at the University of Maryland for providing the field site for this study. Two anonymous reviewers provided peer review of the manuscript and we thank them for their comments. Grants from the National Research Initiative

Competitive Grants Program of USDA 2005-00915, International Society of Arboriculture, TREE Fund, and Gahan and Bamford Fellowships supported this research.

\section{LITERATURE CITED}

Batdorf, L.R. 1994. Boxwood Handbook. American Boxwood Society, Boyce, Virginia, U.S. 123 pp.

Chiriboga, A. 2009. Physiological responses of woody plants to imidacloprid formulations. M.Sc. thesis, Ohio State Univ., Columbus, Ohio, U.S. 130 pp.

d'Eustachio, G., and M.J. Raupp. 2001. Application of systemic insecticides in relation to boxwood leafminer's life history. Journal of Arboriculture 27:255-262.

Frank, S.D., R. Ahern, and M.J. Raupp. 2007. Does imidacloprid reduce defoliation by Japanese beetles on linden for more than one growing season? Arboriculture \& Urban Forestry 33:392-396.

Gagne, R. 1989. The Plant Feeding Gall Midges of North America. Comstock Publishing Associates, Ithaca, New York, U.S. 340 pp.

Gill, S.A., J. Lutz, P.M. Shrewsbury, and S. Klick. 2002. Evaluation of the systemic insecticides imidacloprid and thiamethoxam applied as soil applications for control of boxwood leafminer on boxwood, 2000-2001. Arthropod Management Tests. <www.entsoc.org/Protected/AMT/AMT27/index.asp>

Gupta, G., and V.A. Krischik. 2007. Professional and consumer insecticides for management of adult Japanese beetle on hybrid tea rose. Journal of Economic Entomology 100:830-837.

Holmes, J.J., and J.A. Davidson. 1984. Integrated pest management for arborists: implementation of a pilot program. Journal of Arboriculture 10:65-70.

Lehman, R. 1998. Spruce spider mite, Oligonychus ununguis (Jacobi): An integrated approach to management. Regul. Hort. 190:23-26.
Raupp, M.J., R. Webb, A. Szczepaniec, D. Booth, and R. Ahern. 2004. Incidence, abundance and severity of mites on hemlocks following applications of imidacloprid. Journal of Arboriculture 30:108-113.

Raupp, M.J., A. Szczepaniec, and A. Buckelew Cumming. 2008. Prophylactic pesticide applications and low species diversity: Do they create pest outbreaks in the urban forest? pp. 59-61. In: Proc. of the 18th USDA Interagency research forum on invasive species. Annapolis, Maryland, U.S.

Raupp, M.J., P.M. Shrewsbury, and D.A. Herms. 2010. Ecology of arthropod outbreaks in urban landscapes. Annual Review of Entomology $55: 19-38$

Sadof, C.S., and C. Alexander. 1993. Limitations of cost benefit-based aesthetic injury levels for managing twospotted spider mites. Journal of Economic Entomology 86:1516-1521.

Sadof, C.S., and M.J. Raupp. 1996. Aesthetic Thresholds and Their Development. pp. 203-226. In: L.G. Higley and L.P. Pedigo (Eds.). Economic Thresholds for Integrated Pest Management. University of Nebraska Press, Lincoln, Nebraska, U.S.

Schread, J.C. 1970. Leaf miners and their control. Bulletin 693 of the Connecticut Agricultural Experiment Station. New Haven, Connecticut, U.S. 15 pp.

Sclar, D.C., D. Gerace, and W.S. Cranshaw. 1998. Observations in population increases and injury by spider mites (Acari: Tetranychidae) on ornamental plants treated with imidacloprid. Journal of Economic Entomology 91:250-255.

Shrewsbury, P.M., and M.R. Hardin. 2004. Beat sampling accuracy in estimating spruce spider mite (Acari: Tetranychidae) populations and injury on juniper. Journal of Economic Entomology 97:1444-1449.

Statistix Analytical Software. 2003. Tallahassee, Florida, U.S.

Szczepaniec A., and M.J. Raupp. 2007. Residual toxicity of imidacloprid to hawthorn lace bugs, Corythuca cydoniae, feeding on cotoneasters in landscapes and containers. Journal of Environmental Horticulture 25(1):43-46.

Szczepaniec, A. 2009. Mechanisms underlying outbreaks of spider mites following applications of imidacloprid. Ph.D. dissertation. Univ. of Maryland, College Park, MD. 163 pp.

Szczepaniec, A., S.F. Creary, K.L. Laskowski, J.P. Nyrop, and M.J. Raupp. 2011. Neonicotinoid insecticide imidacloprid causes outbreaks of spider mites on elm trees in urban landscapes. PLoS ONE 6(5): e20018. doi:10.1371/journal.pone.0020018.

Zar, J. 1999. Biostatistical Analysis. Prentice Hall, Upper Saddle River, New Jersey, U.S. 929 pp.

Adrianna Szczepaniec (corresponding author)

Department of Entomology

Texas A\&M University

College Station, Texas 77843, U.S.

Michael J. Raupp

Department of Entomology

University of Maryland

College Park, Maryland 20742, U.S. 
Résumé. Le buis est l'un des arbustes les plus utilisés dans les aménagements paysagers, mais il souffre des attaques fréquentes par la mineuse du buis (Monarthropalpus flavus). L'imidacloprid, un insecticide neocotinoïde, est très efficace pour réduire l'abondance en M. flavus lorsqu'il est vaporisé sur le feuillage ou appliqué sur le sol. Des rapports récents à propos de populations importantes en acariens qui suivaient les applications d'imidacloprid chez d'autres espèces de plantes ligneuses nous ont poussé à faire enquête dans le but de déterminer les effets de l'imidacloprid par rapport à l'abondance en acariens spécialisés, Eurytetranychus buxi, et les dommages qui en résultaient. Les buis traités avec l'imidacloprid hébergeaient significativement plus de E. buxi et présentaient une décoloration plus importante que les buis non traités. Enfin, il y avait une relation directe entre l'abondance en $E$. buxi et la quantité de dommages associés. Les arboriculteurs et les gestionnaires en aménagement paysager devraient être attentifs par rapport à une abondance potentielle élevée en acariens sur les buis ainsi qu'à des degrés de décolorations plus élevés à la suite des applications en imidacloprid.

Zusammenfassung. Buchsbäume gehören zu den meistgenutzten Sträuchern im Landschaftsbau, aber sie sind gefährdet durch die gelegentlichen Attacken des Buchsbaum-Blattbohrers. Das Neo-Nicotinoid-Insektizid Imidacloprid ist hochwirksam bei der Reduzierung des Befalls, wenn es als Blattspray oder als Aufguss auf den Boden verwendet wird. Kürzliche Berichte von gestiegenen Spinnmilben-Populationen nach der Anwendung von Imidacloprid bei anderen Sträuchern verursachte eine Untersuchung, um den Einfluss von Imidacloprid auf eine spezialisierte
Spinnmilbenart auf Buchsbäumen, Eurytetranychus buxi, und den verursachten Schaden zu bestimmen. Buchsbäume, die mit Imidacloprid behandelt waren, beherbergten deutlich mehr $E$ buxi und verursachten mehr Blattflecken als unbehandelte Buchsbäume. Mehrnoch, es gab eine direkte Beziehung zwischen dem massenhaften Auftreten von E. buxi und der Menge an assoziierten Schäden. Arboristen und Landschaftsmanager sollten sich bewusst machen, dass es nach einer ImidaclopridBehandlung ein Potential für massenhaftes Auftreten von Spinnmilben auf Buchsbäumen mit allen damit verbundenen Schäden gibt.

Resumen. El boj o arrayán es uno de los arbustos leñosos de más amplio uso en paisajes, pero sufre de ataques frecuentes por el minador de hoja (Monarthropalpus flavus). El insecticida neonicotinoide imidacloprid es altamente eficaz para reducir la abundancia de M. flavus cuando se aplica como espray foliar o al suelo. Reportes recientes de elevadas poblaciones de arañas de ácaros después de las aplicaciones de imidacloprid a otras especies de plantas leñosas alentó una investigación para determinar los efectos de imidacloprid en la abundancia de una araña especialista Eurytetranychus buxi, y el daño resultante que causa. Los arrayanes tratados con imidacloprid albergaron significativamente más E. buxi y mantuvieron mayor decoloración que los arbustos no tratados. Sin embargo, hubo una relación directa entre la abundancia de E. buxi y la cantidad de daño asociado. Los arboristas y manejadores de paisajes deben estar atentos del potencial de abundancia elevada de ácaros en arrayanes y mayores niveles de decoloración después de las aplicaciones de imidacloprid. 